\title{
STUDY OF OPTIMUM COMPRESSIVE STRENGTH OF PALM KERNEL SHELL - QUARRY DUST AGGREGATES CONCRETE
}

\author{
Damilola. O. Oyejobi ${ }^{1}$, Alao A Jimoh ${ }^{2}$ and Kehinde Abdulsalam Elelu ${ }^{3}$ \\ 1,2,3 Department of Civil Engineering, Faculty of Engineering and Technology, \\ University of Ilorin, Nigeria. \\ oyejobi.do@unilorin.edu.ng, aajimoh4real@yahoo.com, \\ eleluabdulsalam@yahoo.com
}

\begin{abstract}
The suitability of palm kernel shell and quarry dust as coarse and fine aggregates in the concrete were investigated. The materials were pretreated which was followed with determination of physical properties of palm kernel shells and quarry dust as aggregates. A mix design following ACI 211 was used for the concrete mix proportion. Apart from control mix, two replacement levels of coarse aggregates at 50\% and $100 \%$ with palm-kernel shells at $100 \%$ quarry dust were examined. Results show that compressive strength decreased with increase in proportions of palm-kernel shell. For 100,50 , and $0 \%$ palm kernel shells in the concrete containing $100 \%$ quarry dust, the compressive strength at 28 days were $15.06 \mathrm{~N} / \mathrm{mm}^{2}, 17.72 \mathrm{~N} / \mathrm{mm}^{2}$, and $35 \mathrm{~N} / \mathrm{mm}^{2}$ respectively which satisfied the minimum requirement for the production of lightweight concrete. This grade of concrete could be used where low stress concrete is required. Based on the optimum compressive strength of palm kernel shell - quarry dust aggregates concrete, the following inferences were made that the values obtained for specific gravity, water absorption, bulk density, moisture content of palm-kernel shell and quarry dust fall within the range specified for a light weight aggregate. This confirmed that palm-kernel shell and quarry dust could be used as substitute for coarse and fine aggregate respectively to produce light-weight aggregate concrete in non-load bearing structures and in light-weight structural concrete at 1: $1.31: 2.55$ mix ratio.
\end{abstract}

Keywords: Palm kernel shell, quarry dust, mix design, compressive strength, lightweight concrete

\section{INTRODUCTION}

Concrete is the most used material in the construction industry. This is obtained from mixture of binding materials, fine and coarse aggregate, chemical admixtures and water. This has been considered as the cheapest and most readily available material with high resistance to water which can be formed easily when it is fresh Maghfouri et al. (2017). 
Mtallib (2009) reported on flexibility of concrete and its easy adaptability to environmental conditions which make concrete suitable for applications in almost all structures.

The advantages associated with the use of light-weight components has enhanced its use which include light and tough properties to lock down problems associated with use of high density concrete in mega construction Pelisser (2012). The cost of inert materials (aggregates) in the production of concrete has led to the search for quality alternative materials such as palm-kernel shell, glass, and blast furnace slag etc., as either partial or complete substitute for aggregates. Also, the benefits of light-weight aggregate on concrete was identified by Bai and Basheer (2003), to include improved durability properties, low coefficient of thermal conductivity and a higher fire resistant.

From another perspective, waste management is becoming one of the most challenging problems in the world. The rapid growth of industrialization is giving birth to various kinds of wastes which are very dangerous to our environment Singh (2015). Then the use of these waste materials as an alternative to natural non-recycled material in concrete has gained widespread in the construction industry due to the limitations of natural materials and will go a long way in eliminating the adverse and negative effect of it on the environment. Construction by its very nature is not necessarily an environmentally-friendly activity, and this industry has a significant social, economic and environmental impact. The best alternative to achieve sustainable development of the concrete industry is the use of waste and by-product materials instead of raw materials in the concrete mixture Pelisser (2012)

Abutaha (2016) reported Malaysia as the largest producer of palm oil in Asia and the second largest producing country in the world by generating over 3.13 million tons of palm shell as waste which is estimated to grow due to high demand of palm oil. Palm kernel shell is the major pollution problem by producing palm oil clinker and palm oil shell which can be used as a light-weight aggregate in the production of concrete.

Palm kernel shell and blast furnace slag were characterized as coarse aggregate due to their sizes and densities. There have been attempts to use them as coarse aggregate to replace conventional coarse aggregates used for concrete production. In Oyejobi et al. (2012) account, the density of palm kernel shell concrete ranges from 1700 to 2050 $\mathrm{kg} / \mathrm{m}^{3}$. It was also reported byYusuf and Jimoh (2011) that various nominal mixes of the palm-kernel shell concrete could be used as rigid pavement. Results obtained reveal that Nigerian palm kernel shell satisfied the density criterion for both normal and light-weight concrete. Palm kernel shell concrete with nominal mixes of 1:1.5:3 and 1:1:2 satisfied the specifications for rigid pavement. It was reported by Shafigh (2013) that replacing the normal aggregate with oil palm shell in percentages of $12.5 \%$. $25 \%, 37.5 \%$ and $50 \%$ reduces the density of the control mix. Reduction in density of concrete has a significant impact in the use for flooring in the construction of a tower. Alengaram, Al Muhit, and bin Jumaat (2013) reported that the strength, thickness and density of oil palm kernel shell aggregate are lower than those of crushed stone aggregate which are the governing factors for the compressive strength in concrete. The difference between the strength of concrete with and without granulated blast furnace slag was reported to diminish because of density at 7 and 28days when compared to the normal (conventional) mix Shafigh (2013). The compressive strength 
determined after 28 days was $33.01 \mathrm{MPa}$ which is equivalent of concrete of Grade 25 based on the mix design Abutaha (2016), Shafigh (2013) investigated the durability performance of oil palm shell concrete under different curing conditions. Oil palm shell concrete had a 28-day compressive strength, air-dry density and air content of 28 $\mathrm{MPa}, 1965 \mathrm{~kg} / \mathrm{m}^{3}$ and $5 \%$, respectively. It was reported that proper curing is required for oil palm shell concrete to achieve better durability and recommend that the minimum duration of moist curing should be at least 7 days.

Mehta and Monteiro (2006) reported that light-weight concrete with a slump value of $50-75 \mathrm{~mm}$ was similar to a normal concrete with $100-125 \mathrm{~mm}$ adequate for site used. The slump value of mix M37.5 was $50 \mathrm{~mm}$, which shows that the workability of palm kernel shell concrete is still acceptable. Abdullah (1984) achieved slump in the range of 0-260 mm with a compressive strength of $15 \mathrm{MPa}$ when oil palm kernel shell was used in the production of concrete. The aim of this research was to investigate the compressive strength of concrete by incorporating palm kernel shell as artificial aggregates. This is achieved by determining the physical properties of the proposed aggregates, design mix proportion for the palm kernel shell concrete based on the result of physical properties and to investigate compressive strength at different proportions of palm kernel shell.

\section{EXPERIMENTAL DETAILS}

The properties of the materials used in the concrete production and the experimental set-up were carried out according to British and ASTM codes.

\subsection{Materials}

In this research work, the materials used for the production of concrete include; Ordinary Portland Cement (OPC) Grade 42.5, quarry dust, river sand, palm kernel shell (PKS) from a local palm oil producer situated at Omu-Aran, Kwara State, Nigeria, which is located at a Latitude $8^{0} 08^{\prime} 18.85^{\prime} \mathrm{N}$ and Longitude $5^{0} 06$ ' 9.36" E. Water used for all mixes is in accordance toASTM C1602 / C1602M-12 (2012). The fineness grade of river sand used was within $2-4 \mathrm{~mm}$. PKS and quarry dust used as aggregates were shown in Figure 1.

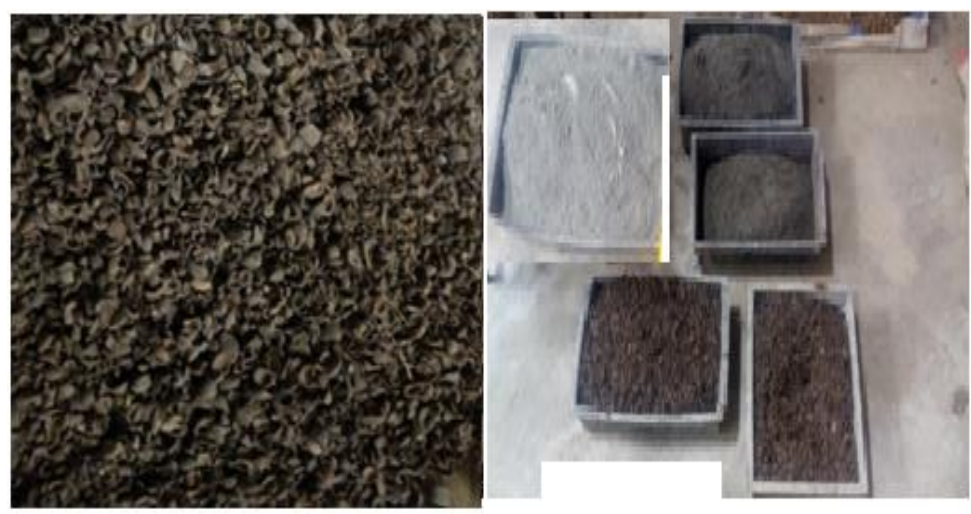

Fig.1: Palm kernel shell and Quarry dust aggregates 


\subsection{Mix Proportions and Curing of Concrete}

Three different mixes were prepared according to ACI C211 (2017) Standard, shown in Table 2.1. The control concrete was made using 100\% granite and 100\% river sand. The mix ratio for 50\% and 100\% palm-kernel shell replacement was 1: 1.31: 2.55 for the production of concrete cubes at water/cement ratio of 0.47 . The moulds used were cleaned with black engine oil to prevent the development of bond between the mould and concrete. The freshly mixed concrete was cast into the mould. Each mould was filled in three layers with the concrete and rammed 25 times with a tamping rod. $100 \mathrm{~mm} \times 100 \mathrm{~mm} \times 100 \mathrm{~mm}$ cubes were produced for the tests with a total of 36 cubes. Concrete cubes were stripped from the mould carefully after 24 hours of the concrete setting under air. All the cubes were cured in water for curing period of 7, 14, 21 and 28 days respectively with an average of three cubes crushed for each test.

Table 1: Mix proportions for Palm-kernel shell - Quarry dust aggregate concrete $\left(\mathrm{kg} / \mathrm{m}^{3}\right)$

\begin{tabular}{cccc}
\hline & Cement & Quarry dust & Granite/PKS \\
\hline 0\% Palm kernel shell (PKS) & 400 & 719 & 439 \\
50\% Palm kernel shell (PKS) & 400 & 525 & 1018 \\
100\% Palm kernel shell (PKS) & 400 & 525 & 1018 \\
\hline
\end{tabular}

\section{METHODOLOGY}

This section discussed the method used for preliminary and hardened property of the concrete.

\subsection{Particle Size Distribution}

This test consists of dividing up and separating by means of a series of test sieves, a material into several particle size classifications of decreasing sizes. The mass of the particles retained on the various sieves is related to the initial mass of the material. The cumulative percentages passing each sieve are reported in numerical and graphical form. The test sieves were arranged from top to bottom in order of decreasing aperture sizes with pan and lid to form a sieving column. The aggregate sample was then poured into the sieving column and shaken thoroughly manually. Sieves were removed one by one starting with the largest aperture sizes (top most), and each sieve shaken manually ensuring no material is lost. All the material which passed each sieve was returned into the column before continuing with the operation with that sieve. The retained material was then weighed for the sieve with the largest aperture size and its weight recorded. The same operation was carried out for all the sieves in the column and their weights recorded. The screened material that remained in the pan was weighed and its weight recorded according to ASTM D6913 - 04 (2009).

\subsection{Specific Gravity and Water Absorption}

The equipment used to carry out this test were a weighing balance, an oven, a wire basket, a water container, an air tight container and a shallow tray. The sample was washed and drained in water at a temperature of $22^{\circ} \mathrm{C}-32^{\circ} \mathrm{C}$, it was then covered to remove entrapped air by shaking gently. The basket and the sample were weighed 
while suspended in water at a temperature of $22^{\circ} \mathrm{C}-32^{\circ} \mathrm{C}$ and this value was recorded as $\mathrm{W} 1(\mathrm{~g})$. The aggregate was then drained of water and spread on a towel to dry for $10 \mathrm{~min}$. The aggregate was weighed and the value was recorded as $\mathrm{W} 3(\mathrm{~g})$, the basket with water was also weighed and recorded as W2 $(\mathrm{g})$. The weight of the oven sample of the aggregate was recorded as W4 (g). The test was carried out according to BS EN 12620 (2008).

\subsection{Maximum Dry Density and Optimum Moisture Content}

For this test, $1 \mathrm{~kg}$ sample of the aggregate was collected and sieved through a $4.75 \mathrm{~mm}$ sieve. The mould was cleaned and greased with oil before the sample was placed in it. The sample was placed in it in layers and its weight was determined. The test follows the British Standard 812 (1995).

\subsection{Bulking of Sand}

The weight of the mould was measured as well as the inner diameter and height, the mould was filled with soil sample in three (3) layers, followed by twenty blows for each layers, and the weight of the mould with filled soil sample. The soil was released into a pan and weighed, sun-dried for forty-eight (48) hours and reweighed using:

$$
\text { Bulk density }=\frac{\text { Total weight of wet soil }}{\text { Volume of mould }} \quad 1
$$

\subsection{Slump Test of Fresh Concrete}

The inner surface of the mould was cleaned and oiled to prevent fresh concrete being stuck on the surface. The mould was placed on the base plate and firmly held. The cone was then filled with fresh concrete in three layer with each layer compacted with 25 strokes of the tamping rod. After filling the mould, the top surface was struck off by means of rolling action of the tamping rod. Immediately after filling, the cone was slowly and carefully lifted and after removal of the mould the slump of the unsupported concrete was measured and recorded.

\subsection{Compressive Strength}

The fresh concrete were cast in iron moulds generally $100 \mathrm{~mm}$ cubes in accordance withASTM C39/C39M - 15a (2015). The moulds surfaces were first cleaned and oiled on their inner surfaces in order to prevent development of bond between the mould and the concrete. The moulds were then assembled, and bolts and nuts tightened to prevent leakage of cement paste. The moulds were filled with concrete in three layers, each layer being compacted using a tamping rod to remove as much entrapped air as possible and to produce full compaction of concrete without segregation. The moulds were filled to overflowing and excess concrete as removed by sawing action of steel rule. The test specimens were then left in the moulds undisturbed for 24 hours and protected against shock, vibration and dehydration. The concrete was cured for 7, 14, 21,28 days at the laboratory. After curing the cubes for the specified period, they were removed and wiped to remove surface moisture in readiness for compression test. The readings on the dial gauge were then recorded for each cube during crushing. 


\section{RESULTS AND DISCUSSION}

This Section discussed results from each experiment conducted, comparison made and discussion are as follows:

\subsection{Particle Size Distribution}

Figs 3.1, 3.2 and 3.3 shows the aggregate particle size distribution for quarry dust, sand and palm kernel shell which helps in determination of various aggregate size used in the concrete production.

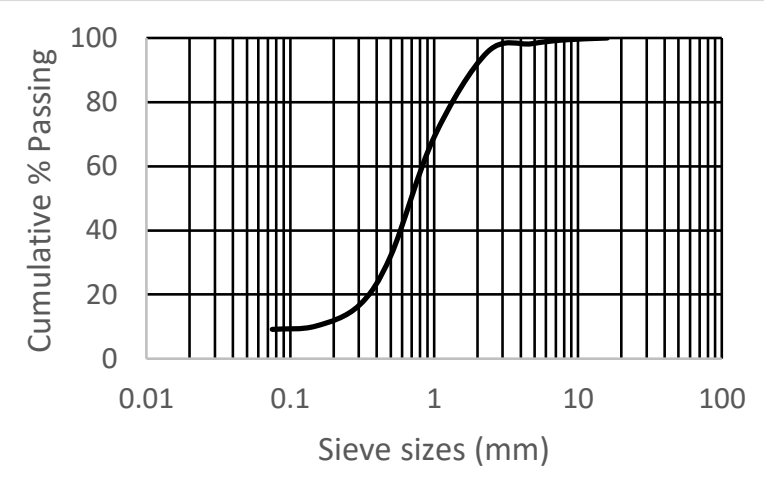

Figure 3.1: Particle size distribution of Quarry dust

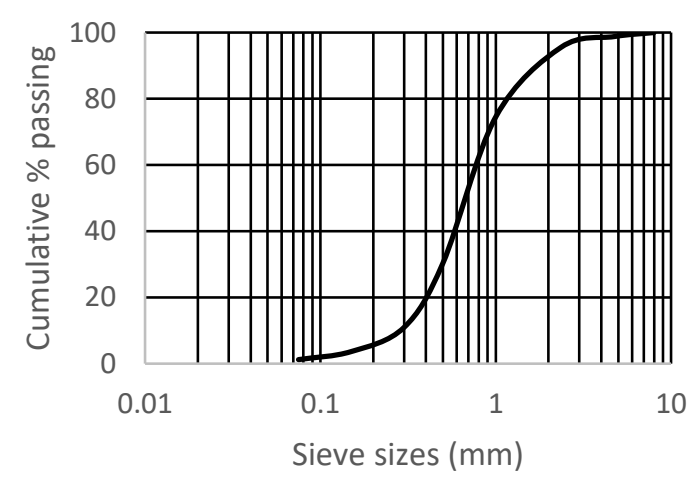

Figure 3.2: Particle size distribution of Sand 


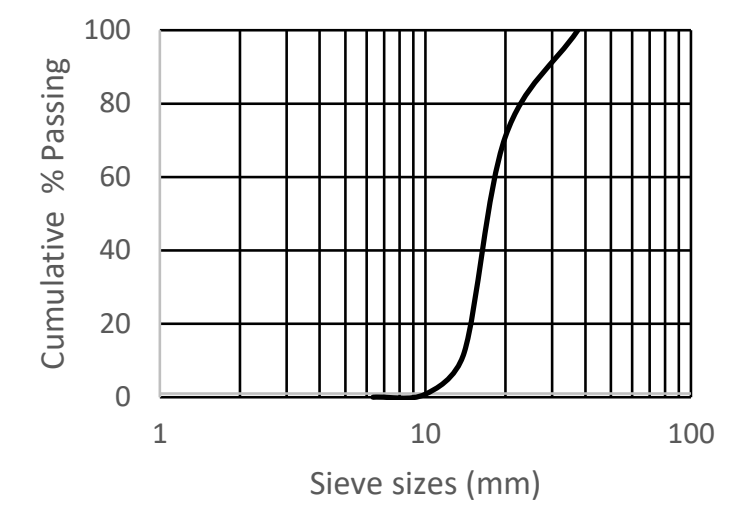

Figure 3.3: Particle size distribution of Palm kernel shell

\subsection{Specific Gravity and Water Absorption}

The specific gravity of palm-kernel shell and granite were determined to be 1.25 and 2.64 , and both are within the range specified for light-weight and normal weight aggregate which are 1.17-1.37 and 2.5-2.9 respectively. The specific gravity determination was used in the preparation of mixed design calculation. Moreover, the average water absorption capacity of palm-kernel shell and granite are $19 \%$ and $0.81 \%$. This value satisfies the specification for water absorption capacity values for both normal and light weight concrete which fall within the range of 5.2-24.5 and $<1$ respectively. Higher value of water absorption capacity in the palm kernel shell compared to granite was due to the presence of pores spaces.

\subsection{Bulk Density of Aggregates}

The bulk density was determined for PKS, Granite, Quarry dust and Sand with the values of $635 \mathrm{~kg} / \mathrm{m}^{3}, 1620 \mathrm{~kg} / \mathrm{m}^{3}, 975 \mathrm{~kg} / \mathrm{m}^{3}$ and $1285 \mathrm{~kg} / \mathrm{m}^{3}$ respectively, PKS fall within the range of $500-850 \mathrm{~kg} / \mathrm{m}^{3}$ which indicate it can be use as light-weight aggregate, while the value of granite falls between $400-1600 \mathrm{~kg} / \mathrm{m}^{3}$ which is the range of normal-weight aggregate. Generally, bulk density is also affected by the size of aggregate and due to lower density, the range of concrete produce fall within 1600$1900 \mathrm{~kg} / \mathrm{m}^{3}$ Alengaram, Al Muhit, and bin Jumaat (2013).

\subsection{Slump Test Fresh Concrete}

The workability of concrete mixes as determined by slump test is shown in Fig. 3.4. The slump value for concrete mix of granite and sand has higher value compared to the palm kernel shell aggregate concrete because of angular and rough edges of palm kernel shell 


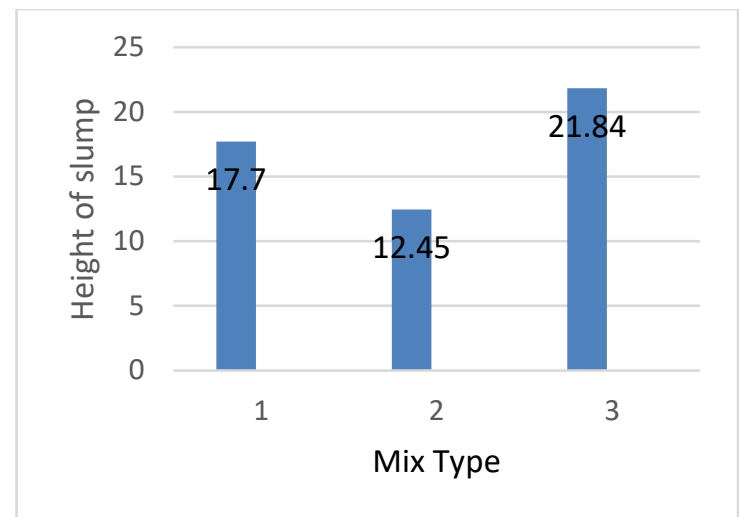

Figure 3.4: Variation of Slump of concrete mix

\subsection{Compressive strength}

At the percentage of palm kernel shell of $50 \%$, the resulting compressive strength at 28 days was $19.720 \mathrm{~N} / \mathrm{mm}^{2}$ against $15.057 \mathrm{~N} / \mathrm{mm}^{2}$ for $100 \%$ as shown in Table 3.1. Olanipekun et al. (2006) also revealed that granite substitution by palm kernel shell decreased the compressive strength. This might be due to either the weaker bond interface between palm kernel shell surface and binder matrix Okpala (1990) or the less strength of the palm kernel shell (Alengaram, Al Muhit, and bin Jumaat (2013). The compressive strength of normal concrete determined was $35.215 \mathrm{~N} / \mathrm{mm}^{2}$ at 28days, which indicate $57 \%$ and $44 \%$ increase in compressive strength as compared to $100 \%$ and $50 \%$ replacement mixed of palm kernel shell concrete respectively.

Table 3.1: Compressive Strength of concrete for various palm kernel shell replacement

\begin{tabular}{|c|c|c|c|}
\hline $\begin{array}{l}\text { Curing age } \\
\text { (Days) }\end{array}$ & $\begin{array}{l}\text { Mix } 1(100 \% \\
\text { PKS) }\end{array}$ & $\begin{array}{l}\text { Mix } 2(0 \% \\
\text { PKS) }\end{array}$ & $\begin{array}{l}\text { Mix } 3(50 \% \\
\text { PKS) }\end{array}$ \\
\hline 7 & 11.13 & 15.54 & 8.10 \\
\hline 14 & 12.20 & 27.70 & 13.60 \\
\hline 21 & 14.76 & 32.99 & 17.57 \\
\hline 28 & 15.06 & 35.45 & 17.72 \\
\hline
\end{tabular}

\section{CONCLUSION}

Based on the optimum compressive strength of palm kernel shell aggregates concrete, the following inferences were made that the values obtained for specific gravity, water absorption, bulk density, moisture content of palm-kernel shell and quarry dust fall within the range specified for a light weight aggregate. This confirms that palm-kernel shell can be used as substitute for coarse and fine aggregate respectively to produce light-weight aggregate concrete. Besides, workability of concrete reduces with increase in palm-kernel shell proportion.

For $100 \%, 50 \%$, and $0 \%$ palm kernel shell concrete, the compressive strength at 28 days were $15 \mathrm{~N} / \mathrm{mm}^{2}, 17 \mathrm{~N} / \mathrm{mm}^{2}$, and $35 \mathrm{~N} / \mathrm{mm}^{2}$ respectively. Concrete containing palm-kernel shell could be used in non-load bearing structures, so therefore, palm- 
kernel could be used as partial or complete substitute for conventional aggregate in light-weight structural concrete at 1:1.31: 2.55 mix ratio.

\section{ACKNOWLEDGMENT}

The first author would like to extend his appreciation to Tertiary Education Trust Fund for sponsoring his conference attendance which was facilitated through the Centre for International Education, University of Ilorin, Nigeria.

\section{REFERENCES}

Abdullah, AA. 1984. Basic strength properties of lightweight concrete using agricultural wastes as aggregates. Paper read at Proceedings of international conference on low-cost housing for developing countries, Roorkee, India.

Abutaha, F., AbdulRasak, H., \& J, K. . 2016. "Effect of palm oil clinker (POC) aggregates on fresh and hardened properties of concrete "Construction and Building Materials:416-423.

ACI C211. 2017. Concrete Mix Design America: ACI.

Alengaram, U Johnson, Baig Abdullah Al Muhit, and Mohd Zamin bin Jumaat. 2013. "Utilization of oil palm kernel shell as lightweight aggregate in concrete-a review." Construction and Building Materials no. 38:161-172.

ASTM C39/C39M - 15a. 2015. Standard Test Method for Compressive Strength of Cylindrical Concrete Specimens. ASTM.

ASTM C1602 / C1602M-12. 2012. Standard Specification for Mixing Water Used in the Production of Hydraulic Cement Concrete. West Conshohocken, PA: ASTM International.

ASTM D6913 - 04. 2009. Standard Test Methods for Particle-Size Distribution (Gradation) of Soils Using Sieve Analysis. ASTM.

Bai, Y, and PAM Basheer. 2003. "Influence of furnace bottom ash on properties of concrete." Proceedings of the Institution of Civil Engineers-Structures and Buildings no. 156 (1):85-92.

British Standard 812. 1995. Methods of determination of bulk densities of aggregate. London, UK: BSI.

BS EN 12620. 2008. Aggregates for concrete. British Standards Institution.

Maghfouri, M, P Shafigh, Z Binti Ibrahim, and V Alimohammadi. 2017. Quality control of lightweight aggregate concrete based on initial and final water absorption tests. Paper read at IOP Conference Series: Materials Science and Engineering.

Mehta, PK, and PJ Monteiro. 2006. Concrete: microstructure, properties, and materials, 297 McGraw-Hill. Vol. 298, New York: McGraw-Hill.

Mtallib, M. O. A., \& Ibrahim, O. 2009. An Investigation into the use of Groundnut Shell as fine Aggregate Replacement. Department of Civil Engineering, A.B.U Zaria, Nigeria. .

Okpala, DC. 1990. "Palm kernel shell as a lightweight aggregate in concrete." Building and environment no. 25 (4):291-296. 
Olanipekun, EA, KO Olusola, O \%J Building Ata, and environment. 2006. "A comparative study of concrete properties using coconut shell and palm kernel shell as coarse aggregates." no. 41 (3):297-301.

Oyejobi, D. O, T. S Abdulkadir, I. T Yusuf, and M. J Badiru. 2012. "Effects of palm kernel shells sizes and mix ratios on lightweight concrete." Journal of Research Information in Civil Engineering no. 9 (2):217-226.

Pelisser, F., Barcelos, A., Santos, D., Peterson, M., \& Bernardin, A. M. 2012. "Lightweight concrete production with low Portland cement consumption." Journal of Cleaner Production no. 23 (1):68-4.

Shafigh, P., Jumaat, M. Z., Mahmud, H. B., \& Alengaram, U. J. . 2013. "Oil palm shell lightweight concrete containing high volume ground granulated blast furnace slag." Construction and Building Materials no. 40:231-238.

Singh, G., Das, S., Ahmed, A. A., Saha, S., \& Karmakar, S. 2015. "Study of granulated blast furnace slag as fine aggregates in concrete for sustainable infrastructure." Procedia-Social and Behavioral Sciences no. 195:2272-2279.

Yusuf, Ibrahim T, and Yinusa A Jimoh. 2011. Palm kernel shell waste recycled concrete road as cheap and environmental friendly freeway on very poor subgrades. Paper read at Proceedings of the National Engineering Conference organized by the Nigerian Society of Engineers. Theme: Effective Transportation System in Nigeria: The Way Forward. 